\title{
PUSAT KEGIATAN BELAJAR MASYARAKAT SEBAGAI TEMPAT ALTERNATIF MENUMBUHKAN KEMANDIRIAN WIRAUSAHA WARGA BELAJAR" (STUDI PADA PKBM INSAN KARYA PAMULANG TANGERANG SELATAN)
}

\author{
GUNARTIN $^{1)}$, SOFFI SOFFIATUN ${ }^{2)}$, H. FEB AMNI HAYATI ${ }^{3)}$ \\ ${ }^{1,2}$ Dosen Program Studi Pendidikan Ekonomi Universitas Pamulang \\ ${ }^{3}$ Dosen Program Studi Manajemen Universitas Pamulang \\ *)email: ${ }^{1)}$ dosen01339@unpam.ac.id
}

\begin{abstract}
ABSTRAK
Pendidikan non formal merupakan salah satu bagian dari pendidikan nasional, dimana warga belajar dapat mengikuti kegiatan belajar yang mandiri melalui penguatan pemberdayaan pendidikan. Sesuai dengan ketetapan pemerintah tentang pendidikan nasional, bahwa pendidikan luar sekolah seperti pusat kegiatan belajar masyarakat juga merupakan bagian dari pendidikan nasional untuk mewadahi warga belajar mensetarakan kedudukannya dengan warga lain yang menempuh pendidikan jalur formal. Makna dasar pusat kegiatan belajar masyarakat adalah pemusatan manajemen dalam hal mencari solusi dalam pemberdayaan sumber daya, yang diselenggarakan dengan latar belakang pembelajaran sehingga output yang dihasilkan dari kegiatan pembelajaran ini mampu meningkatkan soft skill maupun hard skill bagi warga belajar. Dengan demikian diharapkan warga belajar yang menjadikan pusat kegiatan belajar masyarakat (PKBM) sebagai alternatif tempat belajar mempunyai kesetaraan pengetahuan dan ketrampilan yang diperoleh masyarakat dari pendidikan formal. Tujuan dari penelitian ini ingin mendeskripsikan bagaimana kedudukan PKBM di masyarakat dan mendeskripsikan PKBM juga merupakan alternatif menumbuhkan kemandirian berwirausaha.

Peneliti menggunakan pendekatan kualitatif deskriptif untuk metodologi penelitiannya, yaitu pendekatan dengan mendeskripsikan suatu kondisi obyek yang diteliti dengan teknik pengambilan data melalui wawancara. Yang menjadi pusat informasi pada pengumpulan data adalah kepala sekolah atau wakil pusat kegiatan belajar masyarakat sebagai narasumber. Peran peneliti sebagai partisipan penuh dimana peneliti sendiri yang melakukan wawancara. Analisis data didasarkan dari hasil wawancara yang mendalam.

Hasil turun lapang dan analisis data, peneliti simpulkan bahwa PKBM memiliki kesetaraan dengan pendidikan formal dan sangat mungkin sebagai alternatif menumbuhkan kemandirian berwirausaha karena PKBM merupakan pendidikan penyetaraan yang disesuaikan oleh kebutuhan warga belajar dan lebih difokuskan untuk pemberdayaan masyarakat. PKBM Insan Karya sebagai sampel pada penelitian ini menerapkan konsep kecakapan hidup dalam proses pembelajarannya dengan pola tutor sebaya, pelatihan dan kemitraan dalam menumbuhkan kemandirian wirausaha bagi warga belajarnya
\end{abstract}

Kata Kunci: PKBM, kemandirian wirausaha 


\section{Pendahuluan}

Masyarakat yang bermartabat adalah masyarakat yang menjunjung tinggi pendidikan. Menjujung tinggi pendidikan menjadi salah satu tujuan mencerdaskan masyarakat, dimana hal ini terjabarkan pada batang tubuh UUD'45. yaitu untuk membangun martabat dan kualitas masyarakat menunjukkan bahwa bangsa kita ingin masyarakat Indonesia mendapatkan hak yang sama atas pendidikan yang layak. Juga telah ditetapkan dalam UUD'45 tentang hak masyarakat mendapatkan pendidikan yang layak.

Untuk tujuan tersebut departemen pendidikan memberlakukan sistem pendidikan di masyarakat yaitu sistem pendidikan formal dan non formal (pendidikan luar sekolah) dengan harapan semua masyarakat dapat terwadahi untuk mendapatkan pendidikan yang layak dan sesuai dengan bakat dan minat. Wajar jika pusat kegiatan belajar masyarakat tumbuh pesat di lingkungan masyarakat karena memang sangat mendukung program pemerintah dengan perannya tersebut. Pendidikan non formal hadir di tengah-tengah masyarakat bersama pendidikan formal dengan tujuan mewadahi masyarakat yang belum berkesempatan untuk menempuh pendidikan di jalur formal. Pendidikan luar sekolah dalam hal ini adalah pusat kegiatan belajar masyarakat juga merupakan bagian penting yaitu merupakan salah satu pilar yang turut serta mencerdaskan bangsa.

Pendidikan luar sekolah memiliki potensi untuk pembelajaran masyarakat yang sangat fleksibel dimana mampu memenuhi kebutuhan masyarakat sesuai dengan lingkungan budaya, mata pencaharian, usia, jenjang pendidikan ataupun kelompok khusus dalam masyarakat tersebut. Dalam perkembangnya pusat kegaitan belajar masyarakat ini terus melakukan upaya menyesuaian program kesetaraan dengan tuntutan kualifikasi dunia usaha dan industri. Terbukti bahwa, Direktur Pendidikan Luar Sekolah (Dirjen PLS) telah mengembangkan strategi pembelajaran dengan konsep Comming Based Education atau konsep pendidikan berbasis masyarakat. Artinya, pusat kegiatan belajar masyarakat diarahkan mampu beradaptasi dengan perkembangan teknologi informasi dan komunikasi dengan tetap mempertimbangkan 
lingkungan sosial ekonomi dan budaya di lingkungan masyarakat setempat tanpa mengurangi standar pendidikan yang telah ditetapkan.

PKBM pada dasarnya merupakan tempat dimana masyarakat dapat mengikuti program kegiatan belajar yang mandiri melalui penguatan pemberdayaan pendidikan. Sesuai dengan Undang-Undang No. 20 Tahun 2003 tentang pendidikan nasional yang menetapkan PKBM sebagai salah satu pendidikan non formal. Makna dasar pusat kegiatan belajar masyarakat adalah pemusatan manajemen dalam hal mencari solusi dalam pemberdayaan sumber daya, yang diselenggarakan dengan latar belakang pembelajaran sehingga output yang dihasilkan dari kegiatan pembelajaran ini berdampak pada peningkatan soft skill dan hard skill. Dengan demikian diharapkan warga belajar yang menjadikan PKBM sebagai alternatif, mempunyai kesetaraan dengan pengetahuan dan ketrampilan yang diperoleh masyarakat dari pendidikan formal.

Pusat kegiatan belajar masyarakat memfasilitasi dan mengajarkan pada warga belajarnya untuk dapat meningkatkan pengetahuan dan ketrampilan agar bermanfaat bagi mereka dan juga untuk orang lain, yaitu berbagai ilmu pengetahuan, ketrampilan dan ilmu-ilmu penunjang kecakapan hidup, serta memberikan motivasi untuk mandiri dan menumbuhkan jiwa wirausaha. Keterbatasan ekonomi, waktu, usia, kebutuhan hidup, masalah jarak, kebutuhan dunia kerja merupakan beberapa sebab hadirnya lembaga pendidikan yang dikelola oleh masyarakat sebagai pendidikan non formal.

Selain menfasilitasi dan memberikan pembelajaran, menurut Sudjana (1991) PKBM mempunyai tugas: (a) memberikan pembelajaran kepada peserta belajar untuk meningkatkan ketrampilan, kemampuan berkomunikasi maupun beradaptasi dengan perubahan lingkungan di masa mendatang, serta kecakapan dalam menyelesaikan permasalahan hidup, (b) pemberdayaan peserta belajar agar mampu merubah barang yang sudah tidak mempunyai nilai ekonomis menjadi bernilai guna dan bernilai ekonomis.

Berdasarkan latar belakang tersebut, penulis bermaksud melakukan penelitian dengan tema "Pusat Kegiatan 
Belajar Masyarakat Sebagai Tempat Alternatif Menumbuhkan Kemandirian Wirausaha Warga Belajar (Studi Pada PKBM Insan Karya Pamulang Tangerang Selatan)

\section{Rumusan Masalah}

Pusat Kegiatan Belajar Masyarakat secara badan hukum hukum memang merupakan pusat belajar yang berada ditengah-tengah masyarakat untuk mewadahi masyarakat yang terkendala menyelesaikan pendidikan di lingkungan pendidikan formal. Sebagian masyarakat awam masih belum paham dengan baik tentang keberadaan PKBM sehingga kurang begitu peduli untuk tumbuh kembangnya PKBM. Karena PKBM ini berdiri atas dasar kebutuhan masyarakat dari berbagai latar belakang sosial, ekonomi dan pendidikian, harusnya mendapatkan dukungan penuh dari masyarakat sehingga fungsi dari PKBM sebagai pusat belajar masyarakat tidak saja sebagai penyetaraan tetapi mampu sebagai wadah untuk pemberdayaan masyarakat dan menumbuhkan kemandirian wirausaha. Maka dari itu penelitian ini difokuskan pada keinginan peneliti mendskripsikan kedudukan PKBM di masyarakat dan juga mrupakan sebagai alternatif menumbuhkan kemandirian wirausaha selain program yang dicanangkan pemerintah seperti Balai Latihan Kerja (BLK)

\section{Tujuan Penelitian}

Mengacu pada rumusan masalah di atas, penelitian ini bertujuan menggali informasi lebih dalam tentang kedudukan PKBM di masyarakat dan peran PKBM sebagai alternatif menumbuhkan kemandirian wirausaha bagi warga belajar.

\section{Kajian Pustaka}

\section{Konsep PKBM}

Masyarakat menyelenggarakan pusat kegiatan belajar untuk mewadahi peserta belajar yang ingin mensetarakan pendidikannya di jalur pendidikan luar sekolah untuk memenuhi ketuntasan belajar. Secara umum program pendidikan non formal yang dikelola masyarakat dapat diklasifikasikan: 1) program keaksaraan, contoh rumah pintar; 2) program pemberdayaan ekonomi contoh kelompok belajar usaha (KBU); 3) program kesetaraan, seperti paket A setara SD, paket B setara SLTP, dan paket C setara SMA; 4) 
program peningkatan soft skill contoh sulam pita, kreasi sandal hias; 5) program kecakapan hidup contoh pelatihan ketrampilan berkomunikasi, pelatihan strategi mengambil peluang usaha.

Pada implementasinya hanya sebagian saja yang dapat diprogramkan, direncanakan dan diselenggarakan oleh pusat kegiatan belajar masyarakat. Begitu juga dengan PKBM Insan Karya, karena keterbatasan dalam mengelola program-program pendidikan sehingga baru mampu mengelola program kesetaraan. Keterbatasan yang disebabkan oleh faktor sumber daya manusia, pendanaan, sarana dan prasarana, serta faktor penunjang lainnya. Seperti permasalahan PKBM pada umumnya, sehingga pengelolaan PKBM baru mampu menyelenggarakan tiga program. Dengan berbagai pertimbangan dan alasan di atas, PKBM Insan Karya melaksanakan program penyetaraan atau dikenal dengan istilah paket $\mathrm{A}$, paket $\mathrm{B}$ dan paket $\mathrm{C}$ untuk membentuk kemandirian peserta. Program ini diselenggarakan dengan harapan meminimalkan angka anak putus sekolah. Tentunya dengan berbagai ilmu pengetahuan, ketrampilan dan ilmu-ilmu penunjang kecakapan hidup.

PKBM diprakarsai untuk memberikan tempat bagi warga belajar untuk berperan aktif meningkatkan kualitas hidup melalui pendidikan non formal yang diselenggarakan dan dikelola oleh masyarakat. PKBM Insan karya berperan aktif untuk mendorong pemberdayaan masyarakat agar memiliki posisi seimbang dalam kehidupan social maupun ekonominya. PKBM Insan Karya membuat terobosan dengan mendirikan serta menyelenggarakan lembaga kemasyarakatan dengan program yang berinteraksi langsung kepada masyarakat dengan pola struktur sederhana tetapi kaya peran dan fungsi agar pelaksanaan program didasari konsep aktivitas efektif dan efesien.

Dalam penyelenggaraan kegiatan pendidikan yang berbasis msyarakat ini, PKBM Insan Karya memfokuskan kegiatan pembelajarannya pada bidang pendidikan non formal dengan pendekatan sosial ekonomi dan sosial budaya di masyarakat yang cerdas, modern, religius di Kota Tangerang Selatan. Dengan berdiri dan terselenggaranya pusat kegiatan belajar 
masyarakat Insan Karya ingin menunjukkan kepada masyarakat luas bahwa pengetahuan, ketrampiran dan kecakapan hidup tidak hanya dapat diraih dengan belajar di pendidikan formal, tetapi juga dapat diraih di sekolah yang berbasis masyarakat seperti PKBM Insan Karya dimana dalam menyelenggarakan pendidikannya dan membekali warga belajarnya tidak hanya berfokus pada mencari lapangan kerja, tetapi sedapat mungkin dapat menciptakan lapangan kerja baru melalui kegiatan wirausaha.

\section{Kemandirian Wirausaha}

Kemandirian diartikan sebagai suatu keadaan dimana seseoarang denan kekuatannya sendiri berupaya tidak bergantung pada orang lain dalam pengambilan keputusan/tindakan karena adanya sikap percaya diri (Chaplin, 2011). Mengacu pada definisi tersebut kemandirian mempunyai makna percaya bahwa dirinya mampu melakukan sendiri kegiatan yang telah ditetapkan dengan penuh rasa tanggaung jawab, disiplin waktu, dan berani menanggung resiko.

Salah satu aspek kepribadian yang sangat penting adalah kemandirian. Bila seseoarang mempunyai sikap mandiri, cenderung mampu mengatasi segala permasalahan yang dihadapi, sebab ketidak ketergantungan pada pihak lain membuat seseoarng terus berupaya melakukan atau mencari solusi permasalahan yang dihadapi seorang diri.

Pendapat Parker (2005) kemampuan untuk mengelola sumber daya yang dimiliki, waktu, berpikir secara mandiri disertai dengan keberanian mengambil resiko dari setiap pemecahan masalah adalah definisi dari kemandirian. Sehingga dapat dikatakan bahwa suatu hal yang terkait dengan kewajiban seeta soft skill bagaimana teknik perencanaan, pelaksanaan, tujuan yang ingin dicapai serta mengelola sesuatu disebut dengan kemandirian..

Dari beberapa pendapan tentang kemandiran maka dapat disimpulkan bahwa kemandirian adalah adanya kepercayaan terhadap ide diri sendiri dan mempunyai kewenangan untuk menentukan sendiri atau dengan bahasa lain mempunyai otoritas sendiri dalam menentukan langkah berdasarkan kemauan diri..

Seseorang yang berani secara mandiri memproses, melakukan 
identifikasi serta mengembangkan dengan menggerakkan semua sumber daya yang dimiliki merupakan pengerrtian dari wirausaha . Juga dapat diartikan bahwa wirausaha merupakan proses mengidentifikasi, mengembangkan dan membawa tujuan ke dalam kehidupan (Kasali, 2008)

Wirausaha juga dapat diartikan seseorang yang merencanakan, mengkoordinasikan, melaksanakan serta mengevaluasi serta berani mengambil resiko untuk menghadirkan / membuat kesempatan usaha. Berdasarkan pendapat lain yaitu seseoarng yang mempunyai kepekaan mengamati serta meraih kesempatan usaha, mendayagunakan serta memanfaatkan sumber daya untuk dilakukan sebuah tindakan guna mencapai tujuan juga merupakan pemahaman tentang wirausaha.

Sehingga dapat disimpulkan kemandirian wirausaha adalah seseorang yang mempunyai kepercayaan diri serta siap menghadapi tantangan untuk menghasilkan kesempatan usaha. Sikap seperti inilah yang perlu ditumbuhkan dikalangan masyarakat guna membantu membuka lapangan kerja bagi dirinya dan orang lain khususnya, serta membangun ekonomi bangsa secara umum.

\section{Metodelogi Penelitian}

Penelitian ini merupakan penelitian kualitatif dengan pendekatan deskriptif, yaitu suatu pendekatan dengan menfokuskan pada deskripsi data yang berupa pernyataan serta memiliki makna mendalam yang bersumber dari pemberi informasi (narasumber) serta tingkah laku yang diamati, untuk menggali informasi bahwasanya PKBM tidak hanya menyelenggarakan program kesetaraan, tetapi juga dapat dijadikan sebagai alternatif tempat menumbuhkan kemandirian wirausaha bagi warga belajar.

Pengumpulan data dilakukan dengan melakukan wawancara langsung dan narasumber merupakan sumber data primer. Data yang terkumpul merupakan pernyataan hasil interaksi serta wawancara mendalam terhadap informan dan notulen hasil observasi yang didasarkan atas transkrip wawancara, notulen, dan pengamatan langsung oleh peneliti. Menurut Moleong (2007) menyatakan bahwa sumber utama dalam penelitan kualitatif adalah kata-kata dan tindakan, 
selebihnya adalah data-data tambahan seperti dokumen dan sebagainya.

Narasumber untuk menggali informasi pada penelitian ini adalah kepala pusat kegiatan belajar masyarakat, warga belajar dan tutor. Wawancara dilakukan oleh peneliti sendiri sekaligus pengumpul data karena peneliti sebagai instrumen dan bertindak sebagai partisipan penuh. Tempat penelitian difokuskan di pusat kegiatan belajar masyarakat (PKBM) Insan Karya yang beralamatkan di jalan H. Rean no. 42 RT. 05 RW. 02 Kelurahan Benda Baru Kecamatan Pamulang Tangerang Selatan.

Teknik analisis data menggunakan tahapan dalam menganalisis, tahap pertama yaitu tahap penjajakan / obsevasi lapang, maksudnya tahapan dengan melakukan studi permulaan sebagai data alternatif yang nantinya untuk menentukan fokus penelitian. Pada tahap ini peneliti juga mencari sumber referensi dari peneliti terdahulu sebagai data dukung. Hasil temuan Hardjono dan Tri Joko (2016) dinyatakan bahwa pendidikan kesetaraan berbasis kecakapan hidup dan kewirausahaan belum memenuhi tujuan program karena faktor internal dan eksternal, bukan berarti kewirausahaan tidak dapt ditumbuhkan di lingkungan PKBM. Tahap kedua, tahap analisis di lapangan dengan mengikuti proses pengamatan, interaksi langsung atau wawancara mendalam untuk menyajikan situs gugusan peluang dan kekuatan. Konsep dasar yang mengaju pada penjelasan Miles dan Huberman (2007). Analisis situs bertujuan untuk menarik dan memverifikasi kesimpulan tentang situs tunggal, yaitu suatu fenomena dalam kenteks terbatas yang membentuk satu kajian kasus, apakah itu merupakan kasus seorang individu dalam suatu latar, satuan kelompok atau satuan yang lebih luas seperti organisasi, departemen atau komunitas.

\section{Hasil Peneitian}

\section{Kedudukan PKBM di Masyarakat}

Hasil penyelenggaraan kegiatan pembelajaran non formal di luar sekolah contoh program kejar Paket A, Paket B, Paket $\mathrm{C}$ mempunyai kedudukan setara dengan hasil program pendidikan formal disekolah, sehingga memiliki hak elegabilitas yang sama dengan pendidikan formal untuk memasuki satuan pendidikan yang lebih tinggi 
maupun lapangan pekerjaan. Hasil pengumpulan informasi yang diperoleh peneliti menunjukkan bahwa warga belajar yang telah mendapatkan sertifikat penyetaraannya dapat dijadikan syarat masuk perguruan tinggi ataupun memenuhi kualifikasi lowongan pekerjaan bagi progran setara paket $\mathrm{C}$.

Pusat kegiatan belajar yang diprakarsai masyarakat, oleh masyarakat dan diperuntukan pada masyarakat tersebut merupakan salah satu lembaga penyelenggara pembelajaran nonformal di lingkungan masyarakat. PKBM mampu tumbuh dan berkembang apabila penyelenggara kegiatan belajar non formal dan para pemangku kepentingan memiliki kesamaan pandangan sserta tujuan dalam peningkatan kualitas hidup warga masyarakat yang mengalami keterbatasan atau marginalisasi. Pusat kegiatan belajar ini pada awalnya diselenggarakan di tingkat kecamatan kemudian berkembang diselenggarakan di tingkat desa atau kalurahan. Hal ini membuktikan bahwa penyelenggaraan pusat kegiatan belajar ini dibutuhkan oleh masyarakat untuk mewadahi warga masyarakat yang belum berkesempatan menempuh pembelajaran di sekolah formal.

Kegiatan pokok dari pusat kegiatan belajar masyarakat ini adalah memberikan pembelajaran kepada warga belajar melalui berbagai layanan program pendidikan luar sekolah, contoh ketrampilan sulam pita, memasak, atau ketrampilan yang lain yang mampu meningkatkan soft skill dan hard skill warga belajar sebagai pendamping kurikulum formal sesuai ketentuan yang berlaku. Dengan begitu dapat dikatakan bahwa pusat kegiatan belajar ini juga memiliki potensi sebagai lembaga penyelenggara pembelajaran yang mandiri. Walaupun untuk merintis pusat kegiatan belajar ini tidak mudah dan butuh dukungan dari berbagai pihak contohnya dana block grant dari pemerintah, tentu untuk jangka panjang tidak bisa terus bergantung pada bantuan pihak lain. Dengan demikian diharapkan pusat kegiatan belajar mampu tumbuh dan berkembang secara mandiri untuk mencapai tujuannya yaitu membantu warga belajar mensetarakan kedudukannya dengan lulusan sekolah formal melalui penyelenggaraan kegiatan belajar di luar sekolah. 
Bantuan pemerintah tentu sifatnya ekonomi. Warga belajar tidak terbatas arrtinya tidak mungkin pemerintah akan terus menerus memberikan bantuan, maka dari itu PKBM harus berdiri kokoh atas swadaya masyarakat.

Tumbuh kembangnya PKBM dipengaruhi oleh dukungan masyarakat dalam berbagai bentuk antara lain: 1) peran aktif warga masyarakat untuk arah kebijakan; 2) warga masyarakat aktif berpartisipasi dalam penyelenggaraan pusat kegiatan pembelajaran. Penyelenggara pusat kegiatan belajar memperlakukan warga belajar sebagai individu yang memiliki potensi serta kualifikasi untuk mampu memenuhi kebutuhan diri, masyarakat dan lembaga pusat kegiatan belajar itu sendiri. Maka keberadaan pusat kegiatan belajar ini berpotensi sebagai alternatif kegiatan pemberdayaan masyarakat. Dengan kata lain pusat kegiatan belajar ini berupaya untuk mensetarakan warga belajarnya secara seimbang dengan kelompok lainnya yang lebih mampan kehidupan sosial ekonominya, dengan menyediakan layanan pendidikan yang terjangkau sehingga dapat terangkat derajatnya, hak-haknya baik sosial maupun dikondisikan untuk bersaing secara akademik tetapi lebih difokuskan untuk meningkatkan kecakapan hidup sesuai dengan konsep pembelajaran di pusat kegiatan belajar masyarakat Insan Karya.

Kosep kecapakan hidup ini merupakan bagian dari kurikulum pembelajaran di pusat kegiatan belajar dengan harapan secara kecapakan warga belajar mempunyai kesetaraan dengan warga lain yang menuntaskan pendidikan di jalur formal. Hal ini diupayakan atas dasar legalitas lulusan warga belajar setelah menuntaskan masa belajarnya di pusat kegiatan belajar masyarakat. Hal ini membuktikan bahwa kedudukan PKBM setara dengan pendidikan formal lainnya, untuk itu kemampuan warga belajarpun harus diupayakan setara. Dengan keterbatasan dana pengelolaan pusat kegiatan belajar, mengakibatkan layanan kepada warga belajar juga belum mampu menyelenggarakan pembelajaran yang mencakup seluruh program kegiatan pembelajaran, tetapi lebih difokuskan dan ditujukan untuk mengembangkan kemampuan warga 
belajar sesuai tingkatan penyetaraan warga belajar.

Implementasinya proses kegiatan pembelajaran pada pusat kegiatan belajar menerapkan konsep belajar kelompok dengan teman sebaya yaitu warga belajar dalam proses melaksanakan kegiatan belajarnya dilakukan secara bersama warga belajar lainnya. Proses pembelajaran agar lebih tepat guna dan tepat sasaran juga dilakukan dengan pendekatan integratif, yaitu suatu proses pembelajaran lebih ditekankan dan difokuskan pada pembelajaran dengan memadukan berbagai aspek kehidupan masyarakat dalam suatu layanan program pembelajaran pendidikan luar sekolah.

Untuk menjaga dan mepertahankan eksistensi secara berkelanjutan, pusat kegiatan belajar ini harus mampu berkolaborasi dan bersinergi dengan berbagai lembaga lain yang ada di masyarakat penyelenggara aktivitas pendidikan maupun aktivitas lain, contoh salon, bengkel, atau produksi barang dan jasa lainnya serta terus berupaya meningkatkan kompetensi warga belajar agar memenuhi syarat kualifikasi dunia usaha dan industri..

\section{Profil PKBM Insan Karya}

Visi

Terwujudnya PKBM mandiri yang menghasilkan anak-anak yang cerdas, terampil, kreatif, produktif, berbudi pekerti luhur dan mandiri.

\section{Misi}

1. Mewujudkan anak yang kreatif

2. Mewujudkan anak yang mandiri

3. Mewujudkan anak yang bertanggung jawab

4. Mewujudkan anak yang memiliki kecakapan hidup

5. Mewujudkan anak yang cerdas

6. Mewujudkan anak untuk dapat bersaing di era globalisasi

\section{Tujuan}

Yayasan Rumah Belajar Kreatif melalui PKBM Insan Karya mempunyai maksud merealisasi keinginan luhur bangsa Indonesia yang tercantum di Mukadimah Undang-Undang Dasar Republik Indonesia 1945, yaitu mewujudkan kesejahteraan umum dan mencerdaskan kehidupan Bangsa. Atas dasar keinginan luhur tersebut maka Yayasan Rumah Belajar Kreatif berinisiatif merealisasikan Pusat Kegiatan Belajar Masyarakat secara mandiri, berkembang serta berpedoman pada konsep berdaya guna bagi 
kemaslahatan masyarakat. UndangUndang No. 20 Tahun 2003 tentang Sistem Pendidikan Nasional menetapkan, mengakui dan mensetarakan bahwasanya PKBM adalah satuan pendidikan non formal. Kedudukan PKBM ini sama diakuinya seperti sekolah formal yang merupakan satuan pendidikan formal.

\section{Program Pendidikan Kesetaraan}

Salah satu bentuk dari program pendidikan non-formal adalah pendidikan kesetaraan, tentu dalam hal penyelenggaraannya tidak seperti pendidikan formal pada umumnya. Dalam artian bahwa pendidikan ini memang standarnya dibawah pendidikan formal yang mengkondisikan siswanya menguasai berbagai ilmu pengetahuan, namun proses pembelajaran tetap dilaksanakan dengan bersungguh-sungguh mengajarkan kepada warga belajar betapa pentingnya kualitas hidup yang dapat memberikan manfaat bagi keluarga dan masyarakat. Tentunya dengan berbagai ilmu pengetahuan, ketrampilan dan ilmu-ilmu penunjang kecakapan hidup.
Sesuai dengan namanya "Insan Karya", yang menurut tokoh Pembaharuan Islam Indonesia, Nurcholish Madjid atau yang biasa disapa Cak Nur mengartikan "Insan" sebagai manusia sempurna, kepaduan antara akal dan hati, atau selarasnya antara iman, ilmu dan amal. Sedangkan "Karya" adalah kreatifitas. Insan Karya adalah manusia yang imajinatif dan terbuka, siap menghadapi berbagai tantangan yang menghadangnya. Maka dari itu melalui media PKBM Insan Mandiri diharapkan dapat menjadi alternatif warga belajar untuk mendapatkan berbagai ilmu pengetahuan, ketrampilan, dan keahlian sebagai bekal diri. Tentu saja PKBM Insan Karya terselenggara karena di dukung oleh komponen yang memang harus ada yaitu penyelenggara, tutor dan warga belajar.

Penyelenggara

Pendidikan Kesetaraan selaku penanggung jawab program mempunyai tugas membentuk kelompok, menyediakan tempat, menyediakan sarana prasarana, mengatur jadwal, memotivasi, menyusun laporan. Atas tanggung jawabnya yang besar tersebut penyelenggara tidak dapat bekerja 
sendiri. Penting bagi penyelenggara mendapatkan dukungan dari berbagai pihak yaitu masyarakat dan pemerintah dalam mewujudkan tujuan program pembelajaran kesetaraan. Selain itu untuk terwujudnya tujuan program pembelajaran penyetaraan PKBM Insyan Karya menggunakan pendekatan model pembelajaran kesetaraan, yaitu:

- Induktif ( membangun pengetahuan melalui kejadian empirik)

- Konstruktif membangun pandangannya sendiri)

- Tematik ( mengorganisasi pengalaman)

- Berbasis Lingkungan dan

Kecakapan Hidup (relevansi dan kemanfaatan)

Tenaga pengajar atau tutor di PKBM Insan Karya ini diambil dari para relawan yang kompeten di bidangnya masing-masing. Sebagian besar tutor atau pengajar adalah lulusan perguruan tinggi. Diharapkan tutor dapat berbagi ilmu dan pengalamannya sehingga menularkan semangatnya kepada warga belajar. Bagaimanapun, tidak dapat dipungkiri bahwa proses belajar mengajar adalah proses penting dalam penularan karakter. Atas alasan itulah kami PKBM Insan Karya sangat selektif dalam memilih tutor/pengajar. Dalam hal ini Tutor berperan membantu proses belajar mengajar, dengan tugas dan tanggung jawab: menyusun jadwal, menyusun rencana pembelajaran, membuat bahan ajar dan media (alat peraga), mengajar, melatih dan membimbing, menilai kemajuan belajar, melakukan evaluasi pembelajaran, membuat laporan hasil belajar warga belajar.

Setiap warga belajar juga memiliki tugas, fungsi, tanggung jawab, hak dan beban belajar yang harus dipenuhi untuk lancarnya proses pembelajaran. Tugas warga belajar: mengikuti kegiatan belajar mengajar (KBM), mengikuti test atau evaluasi, belajar secara individu atau kelompok, melaksanakan setiap tugas dari tutor, menjaga human relation dengan semua warga elemen lembaga pusat kegiatan belajar masyarakat Insan Karya. Sedangkan peran dari warga belajar adalah sebagai peserta belajar yang penuh kesadaran mengikuti program KBM. Sedangkan tanggung jawabnya mengatur diri sendiri agar dapat mengikuti program belajar mengajar beserta kelompoknya. Haknya warga belajar yaitu mengikuti KBM, 
memperoleh modul atau bahan, mereka berbeda, dengan konsep memperoleh alat tulis, mengikuti test atau ujian. Pelaksanaan kewajiban belajar bagi warga belajar pada program pendidikan kesetaraan dikemas menarik dan menyenangkan dalam kemasan pertemuan tutorial (tatap muka), pelatihan dan praktek keterampilan, serta kegiatan tugas mandiri yang terstruktur sesuai dengan kebutuhan warga belajar.

\section{Menumbuhkan}

Kemadirian

\section{Wirausaha}

Hasil turun lapang melalui wawancara pada salah satu pengelola PKBM Insan Karya, yang peneliti dapat deskripsikan bahwa PKBM Insya Karya dalam proses pembelajarannya mempunyai konsep utama yaitu meningkatkan Life Skill atau kecakapan hidup. Kecakapan hidup merupakan program yang melekat pada kurikulum, dan pada penerapannya tidak didasarkan pada umur atau paket melainkan berdasarkan kecakapan yang sama yang warga belajar miliki. Dengan konsep ini warga belajar merasa lebih nyaman karena mereka tidak merasa dikotakkotak atau diperlakukan beda. Meskipun usia dan latar belakang sosial kecakapan hidup ini mereka merasa senasib dan seperjuangan. .Life Skill bukan konsep yang menjadikan warga belajarnya handal dalam bidang akademik mengingat heteroginnya warga belajar dari berbagai latar belakang sosial, ekonomi dan pendidikan. Konsep kecakapam hidup yaitu konsep yang menyiapkan warga belajar siap menghadapi tantangan hidup dilingkungannya untuk dapat mengambil peluang yang ada. Sedangkan untuk menumbuhkan kemandirian wirausaha memang tidak secara khusus masuk dalam kurikulum melainkan PKBM Insan Karya melaksanakan program kecakapan hidup ini dengan beberapa pola, yaitu:

\section{Tutor Setara}

Tutor setara merupakan konsep warga belajar yang memiliki potensi wirausaha dapat menularkan kegiatan usaha pada warga belajar yang lain.

Contoh yang sudah dilakukan:

a. Ada warga belajar yang sudah mempunyai usaha mie ayam. Warga belajar lain dapat magang di usaha mie tersebut. Dari hasil magang tersebut, 4 (empat) 
warga belajar dari 12 (dua belas) warga belajar yang magang sudah mampu mengikuti jejak berwirausaha dengan membuka usaha mie sendiri.

b. Ada juga warga belajar yang mempunyai Sandal Hias. Bahan dasarnya adalah sandal jepit yang dibalut dengan kain dan diberi aksesoris sehingga menjadi sandal hias yang menarik dan mempunyai nilai ekonomi lebih dibanding sandal hias biasa. Dari pola tutor teman sebaya ini 2 (dua) warga belajar sudah berhasil membuka usaha sandal hias.

Tutor setara ini dikembangkan berdasarkan usaha yang dimiliki warga belajar sehingga setiap tahunnya program yang dijalankan tidak sama. Kelebihannya dengan pola ini pembelajaran tutor setara ini bisa bervariasi. Sehingga dapat meluluskan dengan berbagai keahlian dibidang yang warga belajar dapatkan. Dengan cara mengidentifikasi potensi yang dimiliki warga belajar. Meskipun tidak selalu usaha yang sama dengan tutor sebayanya setidaknya warga belajar sudah mendapatkan ilmu . Mereka dapat mengembangkan sesuai dengan bakatnya sendiri.

\section{Pelatihan}

Pelatihan ini diselenggarakan untuk warga belajar yang disesuaikan dengan kebutuhan program yang sudah berjalan. Misal di Villa Dago, PKBM Insyan Karya mempunyai rekanan pengrajin kain perca. Para warga belajar dapat dilatih untuk menyulam di atas kain perca tersebut sehingga menjadi barang yang bernilai ekonomis. Yang melatih bisa dari tutor PKBM Insan Karya atau langsung di lokasi pengrajin. Warga belajar juga diijinkan mengambil order untuk dikerjakan di rumah warga belajar yang dirasa cakap untuk menyulam.

Pelatihan tidak selalu dilakukan oleh internal PKBM juga dapat meminta bantuan pada dinas-dinas terkait. Misalnya Dinas Koperasi pernah memberikan pelatihan membuat Bubur Ayam dan Soto Betawi bagi warga belajar PKBM Insan Karya.

\section{Kemitraan}

Kota Tangerang Selatan termasuk daerah perkotaan, sehingga mudah bagi PKBM Insan Karya bermitra atau 
bekerja sama dengan berbagai pelaku usaha. Bagi warga belajar yang tidak punya bakat untuk memproduksi atau terlibat langsung dengan kegiatan proses produksi, PKBM Insan Karya dapat melakukan kerja sama dengan mitra. Contoh bermitra dengan distributor olie, maka warga belajar dapat dibina untuk menjadi tenaga pemasar. Atau UNPAM yang mempunyai Kopinmart, warga belajar PBKM Insan Karya bisa ikut menjualkan sebagai mitra.

Kemitraan ini juga dapat dilakukan dengan warga belajar yang sudah lulus dimana awalnya sebagai tutor sebaya. Dipaparkan juga oleh narasumber bahwasanya PKBM Insan Karya juga mempunyai fungsi sebagai inkubator meskipun sifatnya nonformal. Sebagai lembaga inkubasi PKBM Insan Karya bermitra dengan Bank Mandiri untuk pendanaan warga belajar yang membutuhkan modal usaha awal dalam bentuk kredit. Cukup dengan mendapatkan rekomendasi dari pengelola maka warga belajar dapat mengajukan kredit ke Bank Mandiri. Kerja sama atau MoU dengan Bank mandiri ini merupakan inisiatif sendiri untuk membantu warga belajar mendapatkan tambahan modal dalam mengembangkan usahanya.

Parameter untuk tingkat keberhasilan program konsep kecakapan hidup yang dilakukan PKBM Insan Karya dengan melihat berapa banyal lulusan yang mampu mengim[lementasikan ilmunya. Contoh, dari tujuh warga belajar yang mengikuti program teman setara "mie ayam" sudah empat warga belajar yang sudah buka mie ayam sendiri. Konsep kecakapan hidup ini perlu dikembangkan terus untuk menumbuhkan rasa percaya diri dan kemandirian warga belajar. Jika hal ini dapat teus dikembangkan dan banyak warga belajar yang mapan secara ekonomi dari kemandirian tersebut tentu pola ini dapat diadopsi atau diterapkan pada sekolah kejuruan. Paradikma terhadap PKBM yang terbangun juga akan berbeda saat keahlian warga belajar melebihi harapan masyarakat.

\section{Kesimpulan dan Saran}

\section{Kesimpulan}

Negara yang bermartabat adalah negara masyarakatnya berpendidikan. Untuk itu pemerintah memfasilitasi masyarakat dengan jalur pendidikan formal dan non formal. Bentuk 
pendidikan non formal salah satunya yaitu Pusat Kegiatan Belajar Masyarakat (PKBM) yang merupakan alternatif tempat menyelenggarakan proses pembelajaran untuk mewadahi kebutuhan warga belajar dalam hal pendidikan dengan segala keterbatasannya.

Basis

PKBM

dalam menyelengggarakan proses pembelajaran adalah dari msyarakat, dikelola oleh masyarakat dan diperuntukan masyarakat ini difokuskan untuk pemberdayaan masyarakat sebagai bekal menyikapi permasalahan hidup di waktu mendatang, sehingga wajar apabila kedudukan hasil pendidikan non formal menyelenggarakan proses pembelajaraan kesetaraan ini dihargai setara dengan hasil program pendidikan formal, sehingga memiliki hak elegabilitas yang sama dengan pendidikan formal untuk memasuki satuan pendidikan yang lebih tinggi maupun lapangan pekerjaan.

Meskipun memiliki kedudukan yang setara dengan pendidikan formal, ada hal yang membedakan dengan pendidikan formal yaitu konsep pembelajaran. Konsep pembelajarannya khususnya PKBM Insan Karya bukan untuk menyiapkan warga belajar handal dibidang akademik tetapi lebih pada konsep kecakapan hidup dengan pendekatan pola: 1) tutor teman sebaya yaitu yang memiliki usaha wajib menjadi tutor bagi temannya yang belum memiliki usaha; 2) pelatihan, warga belajar diberi pelatihan sebagai bekal sebagai bekal kecakapan hidup sesuai kebutuhan agar tepat sasaran; dan 3) kemitraan, yaitu dengan bermitra/bekerja sama dengan berbagai instansi untuk membekali warga belajar khususnya yang bakatnya bukan memproduksi barang.

Dari hasil turun lapang dimana PKBM Insan Karya sebagai sampelnya dapat peneliti simpulkan bahwa PKBM memang dapat dijadikan sebagai alternatif tempat menumbuhkan kemandirian wirausaha sebagai bekal mencari solusi permasalahan hidup dan menjadikan hidup lebih bermanfaat serta bermartabat.. Dari konsep yang diberlakukan PKBM diharapkan warga belajar mampu menangkap peluang usaha dan mampu bersaing untuk membangun ekonomi keluarga dan ekonomi masyarakat. 


Penelitian ini $r$ memiliki
perkembangan dari penelitian
sebelumnya. Hasil temuan penelitian
sebelumnya kewirausahaan belum bisa
memenuhi harapan tujuan program
penyetaraan, sementara hasil temuan
penelitian ini memberikan harapan pada
masyarakat bahwa PKBM dapat
dijadikan alternatif tempat untuk
menumbuhkan kemandiarian wirausaha

\section{Saran}

Melihat besarnya kontribusi PKBM bagi masyarakat dibidang pendidikan dan ketrampilan kecakapan hidup, saran yang dapat peneliti sampaikan adalah perlunya dukungan penuh dari masyarakat dan pemerintah atas tumbuh kembangnya PKBM. Karena peneliti melihat perkembangan PKBM tidak sepesat pendidikan formal meskipun keduanya memiliki kesetaraan.

Konsep kecakapan hidup perlu diadopsi di jalur pendidkan formal seperti sekolah kejuruan (SMK) untuk membekali mereka menyiapkan diri dengan kualifikasi yang dibutuhkan dunia usaha dan industri jika belum ada kesempatan studi lanjut segera. Orang pintar masih kalah dengan orang kreatif, orang kreatif masih kalah dengan orang yang berani melakukan karena ada kemauan.

Dari penyelenggara PKBM sendiri juga harus berusaha agar PKBM yang dikelola dapat tumbuh mandiri tidak menggantungkan pada bantuan pemerintah. Sehingga operasional PKBM tetap eksis meskipun tidak ada bantuan dari pemerintah, tentu dengan swadaya masyarakat karena PKBM ini asset bagi masyarakat setempat. Jangan sampai begitu bantuan pemerintah dihentikan, berhenti pula operasioanal PKBM.

\section{Daftar Pustaka}

Chaplin, 2011. Kamus lengkap Psikologi. Rajagrafindo Persada. Jakarta

Dirjen Pembinaan Pendidikan Masyarakat RI, Standard dan Prosedur Penyelenggaraan Pusat Kegiatan Belajar Masyarakat (PKBM) Kementrian Pendidikan dan Kebudayaan.

Hardjono dan Tri Joko, 2016. Model Pemberdayaan PKBM dalam Pengelolaan Program Pendidikan Kesetaraan Berbasis Luar Sekolah dan Kewirausahaan. Journal Unes.ac.id

Kasali Rhenald, 2010. Wirausaha Muda Mandiri. Gramedia Pustaka Utama Jakarta 
Meleong, 2007. Metodologi Penelitian Kualitatif. PT. Remaja Rosdakarya. Bandung

Miles, M. B. and A. Huberman, A.M. 2007. Qualitative Data Analysis (terjemahan). UI Press. Jakarta.

Panduan Penyelenggaraan Pusat Belajar Masyarakat, Balai Pengembangan Pendidikan Luar Sekolah dan Pemuda (BP-PLSP), Jayagiri, 2003
Parker, 2005. Menumbuhkan Kemandirian dan Harga Diri Anak. Bandung

Profil Yayasan Rumah Belajar Mandiri Solihin Ismail, 2015. Pengantar Bisnis. Erlangga. Bandung

Undang-Undang No. 20 Tahun 2003 Tentang Sistem Pendidikan Nasional mengakui bahwa PKBM adalah Satuan Pendidikan Non Formal. 